\title{
Hubert Kotarski
}

UNIWERSYTET RZESZOWSKI

E-MAIL: KOTARSKI@UR.EDU.PL

\section{PODOBNI CZY RÓŻNI? POZYCJA SPOŁECZNA \\ I TOŻSAMOŚĆ SPOŁECZNA MŁODZIEŻY EUROPY ŚRODKOWO-WSCHODNIEJ}

\section{Wprowadzenie}

Naczelnym problemem podjętym w badaniach było pytanie, czy kapitał kulturowy i kapitał społeczny są czynnikami tożsamości i pozycji społecznej młodzieży pogranicza, pięciu państw Europy Środkowo-Wschodniej - Polski, Niemiec, Czech, Węgier i Ukrainy - na przykładzie najmłodszego pokolenia - uczniów szkół średnich. Operacjonalizacja problematyki badawczej sprawdzała się do pytania: czy kapitał kulturowy i kapitał społeczny jako czynniki tożsamości i pozycji społecznej najmłodszego pokolenia, upodobniają - uczniów szkół średnich pogranicza: Polski, Niemiec, Czech, Węgier i Ukrainy czy też różnią ich między sobą. W warstwie teoretycznej celem artykułu jest systematyczna konfrontacja teorii kapitału kulturowego Pierre’a Bourdieu oraz teorii kapitału społecznego z rzeczywistością społeczną pogranicza pięciu państw Europy Środkowo-Wschodniej. Konfrontacja ta obejmuje zarówno refleksję o charakterze teoretycznym, skupiającą się na problemie zastosowania teorii Bourdieu oraz teorii kapitału społecznego innych autorów do opisu społeczeństw państw Europy Środkowo-Wschodniej, jak też wyników badań empirycznych zrealizowanych wśród uczniów szkół średnich pogranicz Polski, Niemiec, Czech, Węgier i Ukrainy.

Wyniki analiz omówionych $\mathrm{w}$ tym tekście pochodzą z badania zrealizowanego od marca do czerwca 2015 roku w trzech państwach - Polsce, Węgrzech i Ukrainie. Należy podkreślić w tym, iż mimo faktu, że badania realizowane były na terenie trzech państw to objęły swym zasięgiem pogranicze pięciu państw. Próbę badawczą stanowili uczniowie szkół średnich (ponadgimnazjalnych) w: Słubicach, Zielonej Górze, Raciborzu, Krośnie, 
Rzeszowie, Przemyślu, Hrubieszowie (Polska), Debreczynie (Węgry) oraz Drohobyczu i Użhorodzie (Ukraina). Badanie zrealizowane zostało techniką ankiety audytoryjnej przeprowadzonej w wylosowanych szkołach. Łączna wielkość próby badawczej wynosiła 2900 osób.

\section{Pozycja społeczne i tożsamość społeczna młodzieży pogranicza Europy Środkowo-Wschodniej}

Wybór miejscowości do badań nie był dziełem przypadku. Założeniem badawczym było uchwycenie specyfiki młodzieży pogranicza. Wskazaniu elementów, które wyraźnie różnią przedstawicieli najmłodszego pokolenia poszczególnych pogranicz. Z tego też powodu badania przeprowadzone zostały na kilku pograniczach Europy Środkowo-Wschodniej. Pograniczu polsko-niemieckim - Słubice i Zielona Góra, polsko-czeskim - Racibórz, polsko-słowackim - Krosno i Rzeszów, polsko-ukraińskim - Przemyśl i Hrubieszów, ukraińsko-polskim - Drohobycz oraz węgiersko-ukraińsko-słowackim - Użhorod i Debreczyn.

Pozycja społeczna jest pojęciem o wysokim stopniu ogólności, określającym miejsce zajmowane przez jednostkę w strukturze społecznej. W zależności od tego, jak ujmować będziemy strukturę społeczną, zmieniać się będzie rozumienie pozycji społecznej [Gorlach, Wasilewski 2000: 164]. Interesującą charakterystykę tego pojęcia przeprowadził Piotr Sztompka, charakteryzując je w czterech wzajemnie powiązanych wymiarach: (1) w wymiarze normatywnym (,jak być powinno”), w którym struktura społeczna określana jest jako zinstytucjonalizowane powinności; w perspektywie jednostkowej wymiar ten definiowany jest przez rolę społeczną; (2) w wymiarze świadomościowym - idealnym, w którym tożsamość społeczna określana jest jako zespół przekonań, sądów, idei, nawyków myślowych dotyczących tego, „jak jest”; z perspektywy jednostki zespół ów można określić jako „mentalność pozycyjną” - typowy dla danej pozycji społecznej zbiór ocen, zwłaszcza dotyczących położenia własnej grupy w relacji do innych zbiorowości; (3) w wymiarze interakcyjnym, w którym tożsamość społeczna określana jest poprzez główne kierunki i kanały działań oraz partnerów interakcji; w perspektywie jednostkowej wymiar ten charakteryzują typowe kontakty z innymi - „opcje interakcyjne”; (4) w wymiarze dotyczącym interesów, w którym tożsamość społeczna określana jest jako dostęp do pożądanych dóbr, a tym samym zakres szans życiowych; w perspektywie jednostkowej zróżnicowany dostęp do dóbr (w tym prestiżu, bogactwa, władzy) określany bywa najczęściej jako status 
społeczny [Gorlach, Wasilewski 2000: 164]. Sztompka pisze, że socjologiczne wyjaśnienie tego, co jednostka robi, co myśli, do czego dąży, wymaga zawsze odwołania się do pozycji, którą zajmuje w społeczeństwie, do jej lokalizacji w obrębie struktury społecznej, a tym samym przywołania w eksplanans czterech strukturalnych korelatów pozycji: roli, mentalności, opcji i statusu. Z uwagi na wzajemne powiązanie czterech wymiarów struktury, za nieprawomocne uznać trzeba wszelkie wyjaśnienia jednowymiarowe [Sztompka 1989: 58]. Analizując rozmaite konotacje pojęcia „pozycja społeczna”, silniejsze akcentowanie przez poszczególne paradygmaty badawcze jednych aspektów, a odsuwanie na dalszy plan innych, nie podważają one zasadniczej treści tego pojęcia. „Pozycja społeczna” zawsze odnosi się do cech położenia jednostki (grupy) w strukturze społecznej, zawsze bierze pod uwagę kilka wymiarów (choć jednemu z nich może przypisywać decydujące znaczenie) i zawsze umiejscowienie w strukturze charakteryzowane jest przez relacje, jakie występują między różnymi pozycjami [Gorlach, Wasilewski 2000: 167].

Szerszego omówienia wymaga również, przywołane w tytule artykułu, pojęcie tożsamości. Tożsamość może mieć kluczowe znaczenie w procesie widzenia siebie $\mathrm{w}$ społeczeństwie, postrzeganie innych, a wreszcie sam sposób widzenia społeczeństwa [Wojakowski 2007: 70], w szczególności w przypadku pogranicza, jakim jest obszar objęty badaniem. Pogranicze można zdefiniować jako obszar, na którym odbywają się kontakty społeczno-kulturowe pomiędzy dwoma lub więcej narodami lub grupami etnicznymi kulturowymi oraz następstwa tych kontaktów w postaci kształtowania się nowego człowieka i jego kultury [Sadowski 1992]. Intersujący badawczo jest zatem problem różnic i podobieństw, jakie zachodzą wśród przedstawicieli młodzieży pogranicza państw Europy Środkowo-Wschodniej. Pojęcie tożsamości w socjologii odnosi się najczęściej do sfery autodefinicji aktora społecznego - indywidualnego i zbiorowego. Można w związku z tym określić je jako zbiór wyobrażeń, sądów i przekonań owego aktora o samym sobie [Bokszański 2002: 252]. Terminu tożsamość często używa się wymiennie z terminami identyfikacja i świadomość. Podkreślić należy, że klasyczne socjologiczne teorie tożsamości, opierające się na modelu zdrowia tożsamości, interakcyjnym modelu tożsamości czy też światopoglądowym modelu tożsamości, bazują na założeniu tożsamości jednostkowej. Ostatnio jednak w naukach społecznych można dostrzec tendencję do generalizacji pojęcia tożsamości i rozszerzenia w związku z tym jego zakresu, także na zbiorowości. Mówimy w tym przypadku o różnorodnych postaciach kolektywnych tożsamości: grup etnicznych, ruchów społecznych 
czy też narodów [Bokszański 2002: 252]. Podsumowując można przyjąć, że tożsamość jest utrwaloną, a więc względnie stabilną formą świadomości. Identyfikacja oznacza natomiast tożsamość osobniczą. Jeśli jednostka określa sama siebie, mówi się o jej samoidentyfikacji lub autoidentyfikacji. Chodzi tu więc o swego rodzaju samoświadomość, czyli uświadamianie sobie własnego „ja” postrzeganie swej osobowości, poglądów i zachowań. Na tożsamość osobniczą lub osobową nakłada się tożsamość społeczna, czyli identyfikacja zbiorowa, świadomość społeczna lub tożsamość [Lewandowska 2003]. Tożsamość społeczna jest ponadjednostkowym zbiorem autodefinicji nieredukowalnych do autodefinicji jednostki. Jest ona oparta na przeżywanej i zinternalizowanej tradycji, teraźniejszości i wspólnym dla grupy definiowaniu przyszłości, jest więc bliska pojęciom świadomości zbiorowej, zbiorowym przedstawieniom i wyobrażeniom [Banaszczyk 1989]. Ze względu na charakter badań i traktowanie przedstawicieli poszczególnych pogranicz jako podmiotów analizy badawczej, swoją uwagę skupię na tożsamości społecznej.

Do badanych elementów tożsamości zaliczono poczucie związku z rodziną, własnym narodem, miejscowością, w której badany mieszkał, regionem oraz Europą. Każdy z wymiarów był analizowany z perspektywy każdego z wyróżnionych w badaniu rodzajów pogranicz.

Najsilniejszy związek z własnym narodem deklaruje młodzież na pograniczu polsko-ukraińskim oraz ukraińsko-polskim. Badani na tych dwóch pograniczach charakteryzowali się silnym i bardzo silnym poczuciem związku z własnym narodem (poczucia bycia Polakiem - Ukraińcem) oraz najniższym odsetkiem deklaracji o całkowitym braku związku z narodem $(4,7 \%$ i $4,4 \%)$. Najsłabszym poziomem poczucia związku z własnym narodem charakteryzowała się młodzież zamieszkująca pogranicze węgiersko-ukraińsko-słowackie. Co piąty badany nie czuł żadnego związku $\mathrm{z}$ własnym narodem. Stosunkowo niskim poziomem poczucia związku z własnym narodem charakteryzowała się również młodzież zamieszkująca pogranicze polsko-czeskie (tabela 1). 
Tabela 1. Poczucie związku z własnym narodem a rodzaj pogranicza [\%]

\begin{tabular}{|c|c|c|c|c|c|c|c|}
\hline \multirow{2}{*}{\begin{tabular}{|l} 
Jak silny \\
związek czujesz \\
z: \\
WŁASNY \\
NARÓD
\end{tabular}} & \multicolumn{7}{|c|}{ Rodzaj pogranicza } \\
\hline & PL-UA & PL-SK & PL-UA-SK & PL-CZ & PL-D & H-UA-SK & UA-PL \\
\hline Bardzo silny & 21,8 & 17,6 & 22,7 & 12,8 & 21,4 & 4,2 & 19,1 \\
\hline Silny & 48,2 & 42,1 & 38,8 & 33,2 & 41,1 & 26,3 & 47,3 \\
\hline Słaby & 25,3 & 25,2 & 27,2 & 43,3 & 29,8 & 49,4 & 29,2 \\
\hline $\begin{array}{l}\text { W ogóle nie } \\
\text { czuję związku }\end{array}$ & 4,7 & 15,1 & 11,3 & 10,7 & 7,7 & 20,1 & 4,4 \\
\hline
\end{tabular}

Źródło: opracowanie własne.

Poziom deklaracji respondentów poczucia związku z rodziną z poszczególnych pogranicz był do siebie zbliżony. Nieznacznie silniejszym poziomem poczucia związku z rodziną charakteryzowała się młodzież z pogranicza polsko-niemieckiego i ukraińsko-polskiego (tabela 2).

Tabela 2. Poczucie związku z rodziną a rodzaj pogranicza [\%]

\begin{tabular}{|l|c|c|c|c|c|c|c|}
\hline \multirow{2}{*}{$\begin{array}{l}\text { Jak silny } \\
\text { Związek czujesz } \\
\begin{array}{l}\text { Z: } \\
\text { RODZINA }\end{array}\end{array}$} & PL-UA & PL-SK & PL-UA-SK & PL-CZ & PL-D & H-UA-SK & UA-PL \\
\cline { 2 - 9 } & 65,1 & 69,8 & 67,4 & 64,2 & 74,2 & 64,3 & 72,6 \\
\hline Bardzo silny & 29,1 & 21,4 & 26,7 & 30,5 & 19,2 & 29,7 & 22,2 \\
\hline Silny & 4,5 & 7,5 & 3,8 & 4,2 & 6,3 & 6,0 & 4,7 \\
\hline Słaby & 1,3 & 1,3 & 2,1 & 1,1 & 0,3 & 0,0 & 0,5 \\
\hline $\begin{array}{l}\text { W ogóle nie } \\
\text { czuję związku }\end{array}$ & $\begin{array}{l}\text { PL-UA: polsko-ukraińskie; PL-SK: polsko-słowackie; PL-UA-SK: polsko-ukraińsko-słowackie; PL-CZ: } \\
\text { polsko-czeskie; PL-D: polsko-niemieckie; H-UA-SK: węgiersko-ukraińsko-słowackie; UA-PL: ukraińsko- } \\
\text {-polskie }\end{array}$ \\
\hline
\end{tabular}

Źródło: opracowanie własne.

Najsilniejszy związek z własną miejscowością deklarowała młodzież zamieszkująca pogranicze polsko-słowacko-ukraińskie, ukraińsko-polskie oraz polsko-niemieckie. W przypadku reszty pogranicz poziom deklaracji poczucia przywiązania do własnej miejscowości był na podobnym, zbliżonym do siebie, poziomie (tabela 3). 
Tabela 3. Poczucie związku z miejscowością zamieszkania a rodzaj pogranicza [\%]

\begin{tabular}{|c|c|c|c|c|c|c|c|}
\hline \multirow{2}{*}{\begin{tabular}{|l} 
Jak silny \\
związek czujesz \\
z: \\
MIEJSCOWOŚĆ, \\
W KTÓREJ \\
MIESZKASZ \\
\end{tabular}} & \multicolumn{7}{|c|}{ Rodzaj pogranicza } \\
\hline & PL-UA & PL-SK & PL-UA-SK & PL-CZ & PL-D & $\mathrm{H}-\mathrm{UA}-\mathrm{SK}$ & UA-PL \\
\hline Bardzo silny & 13,5 & 18,5 & 22,3 & 16,6 & 15,4 & 7,8 & 15,3 \\
\hline Silny & 47,8 & 36,9 & 42,6 & 41,7 & 46,4 & 37,7 & 48,4 \\
\hline Słaby & 31,9 & 36,9 & 25,8 & 29,9 & 30,7 & 43,4 & 34,2 \\
\hline $\begin{array}{l}\text { W ogóle nie } \\
\text { czuję związku }\end{array}$ & 6,8 & 7,7 & 9,3 & 11,8 & 7,5 & 11,1 & 2,1 \\
\hline
\end{tabular}

Źródło: opracowanie własne.

Analiza poziomu deklaracji identyfikacji z regionem wykazała, że jest on stosunkowo słabo postrzegany przez młodzież pogranicza, bez względu na jego geograficzne umiejscowienie. Może to być związane, z już wcześniej sygnalizowanym w literaturze, problemem słabej identyfikacji badanych z poziomem mezzostruktur społecznych. Potwierdzają to między innymi badania prowadzone przez Bohdana Jałowieckiego i Grzegorza Gorzelaka, iż poziom identyfikacji, regionalizmu i przywiązania do regionu w państwach postsocjalistycznych jest bardzo słaby [Gorzelak, Jałowiecki 1993]. Zdecydowanie silniej respondenci identyfikują się $\mathrm{z}$ poziomem mikro (rodzina, miejscowość zamieszkania) oraz makro (naród) niż z regionem, który można uznać za poziom mezzostruktury społecznej (tabela 4).

Tabela 4. Poczucie związku z regionem zamieszkania a rodzaj pogranicza [\%]

\begin{tabular}{|c|c|c|c|c|c|c|c|}
\hline \multirow{2}{*}{\begin{tabular}{|l} 
Jak silny \\
związek czujesz \\
z: \\
REGION
\end{tabular}} & \multicolumn{7}{|c|}{ Rodzaj pogranicza } \\
\hline & PL-UA & PL-SK & PL-UA-SK & $\mathrm{PL}-\mathrm{CZ}$ & PL-D & H-UA-SK & UA-PL \\
\hline Bardzo silny & 4,5 & 5,1 & 6,5 & 5,9 & 4,6 & 4,2 & 7,8 \\
\hline Silny & 24,1 & 30,6 & 29,2 & 23 & 23,9 & 16,9 & 39,3 \\
\hline Słaby & 55,3 & 43,9 & 40,5 & 46,5 & 49,8 & 53,9 & 43,2 \\
\hline $\begin{array}{l}\text { W ogóle nie } \\
\text { czuję związku }\end{array}$ & 16,1 & 20,4 & 23,7 & 24,6 & 21,7 & 25,0 & 9,7 \\
\hline
\end{tabular}

Źródło: opracowanie własne. 
Młodzież pogranicz charakteryzowała się stosunkowo słabym poczuciem związku z Europą (tabela 5).

Tabela 5. Poczucie związku z kontynentem zamieszkania a rodzaj pogranicza [\%]

\begin{tabular}{|c|c|c|c|c|c|c|c|}
\hline \multirow{2}{*}{\begin{tabular}{|l|} 
Jak silny \\
związek czujesz \\
z: \\
EUROPA \\
\end{tabular}} & \multicolumn{7}{|c|}{ Rodzaj pogranicza } \\
\hline & PL-UA & PL-SK & PL-UA-SK & PL-CZ & PL-D & H-UA-SK & UA-PL \\
\hline Bardzo silny & 7,0 & 8,9 & 10,3 & 7,5 & 9,9 & 8,3 & 10,2 \\
\hline Silny & 25,5 & 22,9 & 23,7 & 29,4 & 29,9 & 21,9 & 30,1 \\
\hline Słaby & 45,4 & 45,2 & 38,8 & 38,0 & 40,2 & 36,9 & 41,5 \\
\hline $\begin{array}{l}\text { W ogóle nie } \\
\text { czuję związku }\end{array}$ & 22,1 & 22,9 & 27,1 & 25,1 & 20,0 & 32,9 & 18,2 \\
\hline \multicolumn{8}{|c|}{$\begin{array}{l}\text { PL-UA: polsko-ukraińskie; PL-SK: polsko-słowackie; PL-UA-SK: polsko-ukraińsko-słowackie; PL-CZ: } \\
\text { polsko-czeskie; PL-D: polsko-niemieckie; H-UA-SK: węgiersko-ukraińsko-słowackie; UA-PL: ukraińsko- } \\
\text {-polskie }\end{array}$} \\
\hline
\end{tabular}

Źródło: opracowanie własne.

\section{Kapitał kulturowy i społeczny młodzieży pogranicza Europy Środkowo-Wschodniej}

Kapitał społeczny i kulturowy stały się jednymi z najczęściej używanych pojęć w naukach społecznych w ostatnich latach. Teorie zajmujące się tymi dwoma typami kapitałów okazały się szczególnie użyteczne w przypadku próby wyjaśniania przemian zachodzących $\mathrm{w}$ ramach struktury społecznej społeczeństw postkomunistycznych. Przemiany te można ujmować na poziomie zmiany postaw oraz zachowań w życiu przedstawicieli różnych kategorii społecznych. Można również zmierzać do uchwycenia ich następstw na poziomie ogólnych mechanizmów oraz kierunków ruchliwości w obrębie wertykalnym - warstw i klas, lub ruchliwości zachodzącej w wymiarze horyzontalnym pomiędzy różnymi segmentami struktury społecznej [Bartoszek 2003: 7]. Szczególną użyteczność teorii kapitału kulturowego Pierre’a Bourdieu, jak i samego pojęcia kapitału kulturowego, do analizy zmian zachodzących w społeczeństwach Europy Środkowej i Wschodniej po 1989 roku podkreślał Ivan Szelényi. Pisał on, że bezprecedensowy wzrost wartości kapitału kulturowego jest wyraźnie widoczny, gdy uwzględni się skład klasy politycznej, która doszła do władzy w ostatnich latach. Władza w społeczeństwach postkomunistycznych jest w pełni kontrolowana przez intelektualistów i specjalistów. Prezydenci, premierzy, ministrowie, parlamentarzyści, burmistrzowie i niemal wszystkie czołowe osobistości w par- 
tiach rządzących i opozycyjnych to intelektualiści lub specjaliści. W krajach kapitalistycznych specjaliści odgrywają ważną rolę w polityce, lecz są to zazwyczaj prawnicy lub ekonomiści. Inteligencja humanistyczna rzadko dostaje się na szczyty drabiny politycznej. W społeczeństwach postkomunistycznych natomiast, zajmowanie kluczowych pozycji w strukturach władzy przez inteligencję humanistyczną jest nie tyle wyjątkiem, ile raczej regułą. Czołowymi politykami postkomunistycznymi są dramaturdzy, historycy, socjologowie, antropologowie i filozofowie [Szelényi, Treiman, Wnuk-Lipiński 1995: 17].

W literaturze naukowej pojęcie kapitału kulturowego używane jest przede wszystkim w odwołaniu do teorii reprodukcji struktury społecznej Pierre’a Bourdieu, a rozwijanej we współpracy z Jean-Claude Passeronem. Według P. Bourdieu i J.-C. Passerona kapitał kulturowy jednostki jest najsilniej warunkowany przez wykształcenie oraz zawód ojca i oddziałuje na poziom jej osiągnięć szkolnych [Bourdieu, Passeron, Neyman 1990: 130-131]. Kapitał kulturowy studentów pochodzących z klas wyższych daje im wyraźną przewagę nad studentami wywodzącymi się z klas niższych w przechodzeniu selekcji społecznej, poczynając od wcześniejszych szczebli edukacji, sprzyja im w uzyskiwaniu miejsc na lepszych kierunkach studiów i osiąganiu lepszych wyników [Bourdieu, Passeron, Neyman 1990: 152-153]. Podsumowując można stwierdzić, że koncepcja tak eksplikowanego kapitału kulturowego umożliwia pogłębienie wyobrażeń o roli statusu społecznego rodziców w osiąganiu wyższych pozycji przez ich dzieci [Bartoszek 2003].

Jako główny miernik kapitału kulturowego wyniesionego $\mathrm{z}$ domu rodzinnego potraktowano w niniejszych badaniach dwa czynniki: wykształcenie rodziców oraz liczbę książek znajdującą się w domowych biblioteczkach badanych. Na podstawie odpowiedzi na te trzy pytania opracowano syntetyczny wskaźnik, na który składało się wykształcenie ojca (waga 33,3\%), wykształcenie matki (waga 33,3\%) oraz liczba książek $\mathrm{w}$ domu rodzinnym.

Najwyższym poziomem rodzinnego kapitału kulturowego charakteryzuje się młodzież zamieszkująca pogranicze polsko-niemieckie, węgierskoukraińsko-słowackie oraz ukraińsko-polskie. Najniższym zaś polsko-czeskie i polsko-słowackie (tabela 6). Najlepiej wykształceni byli rodzice uczniów z pogranicza polsko-niemieckiego oraz ukraińsko-polskiego. Warto również zauważyć, iż generalnie wyższym poziomem wykształcenia charakteryzowały się na tych pograniczach matki niż ojcowie. Również ciekawą zależnością, którą warto podkreślić, był fakt, iż poziom wykształcenia rodziców 
determinuje wielkość domowego księgozbioru. Na podstawie zebranych wyników badań dotyczących poziomu wskaźnika rodzinnego kapitału kulturowego można przypuszczać, że w przypadku uczniów szkół średnich dziedziczony kapitał kulturowy może stanowić czynnik warunkujący dostęp do studiów wyższych. Świadczyć może o tym analiza odpowiedzi na pytanie o przyszłość edukacyjną i zawodową oraz preferowany do podjęcia przez badanych kierunek studiów. Młodzież z wyższym poziomem kapitału kulturowego częściej deklarowała chęć podjęcia studiów wyższych, częściej również wskazywała kierunki studiów cieszące się wysokim prestiżem społecznym, takie jak medycyna czy prawo.

Tabela 6. Wskaźnik rodzinnego kapitału kulturowego a rodzaj pogranicza [\%]

\begin{tabular}{|l|c|c|c|c|c|c|c|}
\hline \multirow{2}{*}{$\begin{array}{c}\text { Poziom } \\
\text { wskaźnika }\end{array}$} & \multicolumn{7}{|c|}{ Rodzaj pogranicza } \\
\cline { 2 - 9 } & PL-UA & PL-SK & PL-UA-SK & PL-CZ & PL-D & H-UA-SK & UA-PL \\
\hline Niski & 34,9 & 35,4 & 34,3 & 46,9 & 31,4 & 31,3 & 20,9 \\
\hline Średni & 31,7 & 40,8 & 36,7 & 22,3 & 31,1 & 31,0 & 47,5 \\
\hline Wysoki & 33,4 & 23,8 & 29,0 & 30,7 & 37,5 & 37,6 & 31,6 \\
\hline Ogółem & 100,0 & 100,0 & 100,0 & 100,0 & 100,0 & 100,0 & 100,0 \\
\hline $\begin{array}{l}\text { PL-UA: polsko-ukraińskie; PL-SK: polsko-słowackie; PL-UA-SK: polsko-ukraińsko-słowackie; PL-CZ: } \\
\text { polsko-czeskie; PL-D: polsko-niemieckie; H-UA-SK: węgiersko-ukraińsko-słowackie; UA-PL: ukraińsko- } \\
\text {-polskie }\end{array}$
\end{tabular}

Źródło: opracowanie własne.

Wśród badaczy zajmujących się problematyką kapitału społecznego występuje pewna różnica w definiowaniu jego podstawy. Nie ma jednak wątpliwości, że wspólnym dla zdecydowanej większości autorów strukturalnym elementem kapitału społecznego jest zaufanie społeczne. Jest ono zasadniczym składnikiem kapitału społecznego i jedną z jego najcenniejszych odmian [Sztompka 2007: 244]. Dla wielu teoretyków zaufanie jest kluczową kategorią i wartością, a jego występowanie świadczy o wysokim poziomie kapitału społecznego [Szawiel 2006].

W ramach analizy tego wymiaru kapitału społecznego zbudowano syntetyczny wskaźnik zaufania społecznego, składający się z sześciu elementów - wskaźników: (1) Czy większości sąsiadów mogę zaufać, (2) Czy w sąsiedztwie większość osób jest gotowych cię wykorzystać, (3) Czy większości mieszkańców mojej miejscowości można zaufać, (4) Czy mój wykładowca (nauczyciel) jest osobą, do której mogę się zwrócić, (5) Czy na większość kolegów/koleżanek $\mathrm{z}$ szkoły mogę liczyć $\mathrm{w}$ razie potrzeby, (6) Czy większość władz mojej miejscowości to ludzie godni zaufania. 
Tabela 7. Wskaźnik zaufania społecznego a rodzaj pogranicza [\%]

\begin{tabular}{|l|c|c|c|c|c|c|c|}
\hline \multirow{2}{*}{$\begin{array}{c}\text { Poziom } \\
\text { wskaźnika }\end{array}$} & \multicolumn{7}{c|}{ Rodzaj pogranicza } \\
\cline { 2 - 8 } & PL-UA & PL-SK & PL-UA-SK & PL-CZ & PL-D & H-UA-SK & UA-PL \\
\hline Niski & 38,5 & 32,1 & 41,3 & 24,7 & 31,9 & 42,9 & 34,1 \\
\hline Średni & 31,2 & 29,9 & 26,0 & 29,9 & 33,5 & 32,9 & 36,5 \\
\hline Wysoki & 30,3 & 38,0 & 32,8 & 45,5 & 34,6 & 24,2 & 29,4 \\
\hline Ogółem & 100,0 & 100,0 & 100,0 & 100,0 & 100,0 & 100,0 & 100,0 \\
\hline $\begin{array}{l}\text { PL-UA: polsko-ukraińskie; PL-SK: polsko-słowackie; PL-UA-SK: polsko-ukraińsko-słowackie; PL-CZ: } \\
\text { polsko-czeskie; PL-D: polsko-niemieckie; H-UA-SK: węgiersko-ukraińsko-słowackie; UA-PL: ukraińsko- } \\
\text {-polskie }\end{array}$
\end{tabular}

Źródło: opracowanie własne.

Najwyższym poziomem zaufania społecznego charakteryzowali się uczniowie z pogranicza polsko-czeskiego. Nieco niższy poziom zaufania społecznego odnotowano dla uczniów pogranicza polsko-niemieckiego oraz polsko-słowackiego. Zdecydowanie najniższym poziomem zaufania społecznego charakteryzowała się badana młodzież zamieszkująca pogranicze węgiersko-ukraińsko-słowackie oraz ukraińsko-polskie (tabela 7).

\section{Podsumowanie}

Badania wykazały różnice w poziomie zasobów kapitału kulturowego i społecznego. Przełożyło się to na różnice na poziomie analizy tożsamości i pozycji społecznej młodzieży - uczniów szkół średnich, pogranicza trzech państw Europy Środkowo-Wschodniej - Polski, Węgier i Ukrainy. Celem badań była próba zmierzenia poziomu identyfikacji ze strukturami społecznymi na poziomie: makro - naród, Europa, mezzo - region oraz mikro - rodzina i miejscowość, w której mieszka badany. Badania wykazały, że najsilniejszy związek z własnym narodem deklaruje młodzież na pograniczu polsko-ukraińskim oraz ukraińsko-polskim. Najsłabszym zaś poziomem deklaracji z własnym narodem charakteryzowała się młodzież zamieszkująca pogranicze węgiersko-ukraińsko-słowackie. Analiza poziomu deklaracji identyfikacji z regionem wykazała, że jest on stosunkowo słabo identyfikowany przez młodzież pogranicza, bez względu na jego geograficzne umiejscowienie. Najsilniejszy związek z własną miejscowością czuje młodzież zamieszkująca pogranicze polsko-słowacko-ukraińskie, ukraińsko-polskie oraz polsko-niemieckie. W przypadku reszty pogranicz poziom deklaracji był na podobnym, zbliżonym do siebie, poziomie. Analiza poczucia związku z rodziną, wykazała, że poziom deklaracji respondentów z poszczególnych 
pogranicz był do siebie zbliżony. Jedynie nieznacznie silniejszym poziomem poczucia związku z rodziną charakteryzowała się młodzież z pogranicza polsko-niemieckiego i ukraińsko-polskiego.

Analiza zasobów kapitału kulturowego i społecznego młodzieży badanego pogranicza Europy Środkowo-Wschodniej pozwoliła na uchwycenie kilku interesujących problemów. Najwyższym poziomem rodzinnego kapitału kulturowego charakteryzuje się młodzież zamieszkująca pogranicze polsko-niemieckie, węgiersko-ukraińsko-słowackie oraz ukraińsko-polskie. Najniższym zaś polsko-czeskie i polsko-słowackie. Najlepiej wykształceni byli rodzice uczniów z pogranicza polsko-niemieckiego oraz ukraińskopolskiego. Najwyższym poziomem zaufania społecznego charakteryzowali się uczniowie z pogranicza polsko-czeskiego. Nieco niższy poziom zaufania społecznego odnotowano dla uczniów pogranicza polsko-niemieckiego oraz polsko-słowackiego. Zdecydowanie najniższym poziomem zaufania społecznego charakteryzowała się badana młodzież zamieszkująca pogranicze węgiersko-ukraińsko-słowackie oraz ukraińsko-polskie. Okazało się również, iż syntetyczny wskaźnik zaufania społecznego jest skorelowany z badanymi elementami tożsamości społecznej: poczuciem związku $\mathrm{z}$ rodziną, własnym narodem, miejscowością, regionem i Europą. Wysoki poziom zaufania wiązał się z wysokim poziomem poczucia przywiązania z poszczególnymi elementami, analizowanej w badaniach, tożsamości społecznej. W przypadku analizy poziomu zaufania i związku z własnym narodem współczynnik korelacji rangowej d Sommersa wykazał najsilniejszy związek na pograniczu polsko-słowackim (wartość współczynnika d Sommersa $=0,315$ ), polsko-ukraińsko-słowackim (współczynnik d Sommersa $=0,276$ ) oraz węgiersko-ukraińsko-słowackim (współczynnik d Sommersa $=0,252$ ). Analiza korelacji poziomu zaufania i poczucia związku z rodziną była najsilniej widoczna na pograniczu polsko-słowacki (wartość współczynnika d Sommersa $=0,307$ ) oraz polsko-czeskim (wartość współczynnika d Sommersa $=0,141$ ). W przypadku analizy poziomu zaufania i związku z miejscowością, w której mieszkali badani najsilniejszy związek odnotowano na pograniczu polsko-słowackim (wartość współczynnika d Sommersa $=0,450$ ), polsko-ukraińsko-słowackim (współczynnik d Sommersa = 0,261) polsko-niemieckim (współczynnik d Sommersa $=0,254$ ) oraz polsko-czeskim (współczynnik d Sommersa $=0,234$ ). Analiza korelacji poziomu zaufania i poczucia związku z regionem była najsilniej widoczna na pograniczu ukraińsko-polskim (wartość współczynnika d Sommersa $=0,309)$. Najsilniejszy związek między poziomem zaufania a poczuciem związku z Europą, na poziomie współczynnika kore- 
lacji rangowej dSommersa, stwierdzono na pograniczu polsko-słowackoukraińskim. Wartość współczynnika d Sommersa wyniosła 0,262.

Podjęte badania stanowią jedynie fragment bardzo interesującego problemu badawczego, jakim są badania pogranicza, a w szczególności najmłodszego pokolenia wchodzącego w świat dorosłego życia społecznego, obywatelskiego i zawodowego. Analiza zachowań i zasobów kapitału kulturowego i społecznego może mieć kluczowe znaczenie w przyszłości, ponieważ młodzi ludzie będę w niedługiej przyszłości stanowić trzon elity intelektualnej pogranicz Europy Środkowo-Wschodniej.

\section{Bibliografia}

Banaszczyk T. (1989), Studia o przedstawieniach zbiorowych czasu i przestrzeni w durkhejmowskiej szkole socjologicznej, Wrocław.

Bartoszek A. (2003), Kapitał społeczno-kulturowy młodej inteligencji wobec wymogów rynku, Katowice.

Bokszański Z. (2002), Tożsamość, [w:] W. Kwaśniewicz (red.), Encyklopedia socjologii, t. 4, Warszawa.

Bourdieu P., Passeron J.-C., Neyman E. (1990), Reprodukcja: Elementy teorii systemu nauczania, Warszawa.

Gorlach K., Wasilewski J. (2000), Pozycja społeczna, [w:] H. Domański, Z. Bokszański (red.), Encyklopedia socjologii, Warszawa.

Gorzelak G., Jałowiecki B. (red.) (1993), Czy Polska będzie państwem regionalnym? Seria: Studia regionalne i lokalne, $\mathrm{nr}$ 42, Warszawa.

Lewandowska I. (2003), Historyczna świadomość regionalna: $Z$ badań nad młodzieża licealna Warmii i Mazur, Olsztyn.

Sadowski A. (1992), Pogranicze. Studia społeczne. Zarys problematyki, „Pogranicze. Studia Społeczne", t. 1.

Szawiel T. (2006), Społeczeństwo obywatelskie i kapitał społeczny $w$ Polsce na przełomie wieków (1995-2001), [w:] A. Miszalska, A. Piotrowski (red.), Obszary ładu i anomii. Konsekwencje i kierunki polskich przemian, Łódź.

Szelényi I., Treiman D., Wnuk-Lipiński E. (1995), Elity w Polsce, w Rosji i na Wegrzech: Wymiana czy reprodukcja?, Warszawa.

Sztompka P. (1989), Pojęcie struktury społecznej: próba uogólnienia, „Studia Socjologiczne“, nr 3.

Sztompka P. (2007), Zaufanie: Fundament społeczeństwa, Kraków.

Wojakowski D. (2007), Swojskossć i obcość w zmieniającej się Polsce, Warszawa. 


\section{SUMMARY}

\section{Similar or different? Social position and identity of youth of Central and Eastern Europe}

The aim of the article is to confront the theory of cultural capital and social capital from the social reality in the border regions of the three countries: Poland, Hungary and Ukraine, with particular emphasis on the role played by young people in these societies. This confrontation will include both a theoretical reflection, focusing on the problem of the application of the theory of cultural and social capital to describe societies of the countries of Central and Eastern Europe, and also the results of empirical studies carried out among high school students in Poland, Hungary and Ukraine. The specific objective of the article is to analyze the concept of cultural capital and social capital as a factor of identity and social position and political youth Poland, Hungary and Ukraine, for example, the youngest generation.

KEYWORDS: Cultural capital, Social capital, Identity, Central and Eastern Europe, Youth 